\title{
PENGARUH KUALITAS JASA PERBANKAN TERHADAP LOYALITAS NASABAH TABUNGAN SIMPEDES DI BANK RAKYAT INDONESIA KANTOR UNIT CABANG SENTANI KABUPATEN JAYAPURA
}

\author{
Markus Setiawan Soumokil 1 \\ markussetiawansoumokil13@gmail.com \\ Abdul Kharis Kamaruddin ${ }^{2}$ \\ kharis.abdul@gmail.com \\ 1-2 Fakultas Ekonomi dan Bisnis Universitas Cenderawasih
}

\begin{abstract}
Abstraksi:
Penelitian ini bertujuan 1) Untuk mengetahui pengaruh Kualitas Jasa (bukti langsung, kehandalan, daya tanggap, jaminan dan empati) secara parsial terhadap Loyalitas Nasabah BRI Kantor Unit Sentani Kabupaten Jayapura. 2) Untuk mengetahui pengaruh Kualitas Jasa (bukti langsung, kehandalan, daya tanggap, jaminan dan empati) secara simultan terhadap Loyalitas Nasabah BRI Kantor Unit Sentani Kabupaten Jayapura. 3) Untuk mengetahui faktor di antara bukti langsung, kehandalan, daya tanggap, jaminan dan empati yang berpengaruh dominan terhadap Loyalitas Nasabah BRI Kantor Unit Sentani Kabupaten Jayapura. Metode penelitian yang digunakan dalam penelitian adalah Deskriptif kuantitatifdilaksanakan pada bulan Juni tahun 2020.Populasi sebanyak 100 orang. Sampel sebanyak 100 orang. Hasil penelitian menunjukkan bahwa 1) Bukti Langsung berpengaruh positif dan signifikan terhadap Loyalitas Nasabah BRI Kantor Unit Sentani Kabupaten Jayapura. 2) Kehandalan berpengaruh positif dan signifikan terhadap Loyalitas Nasabah BRI Kantor Unit Sentani Kabupaten Jayapura 3) Daya Tanggap tidak berpengaruh terhadap Loyalitas Nasabah BRI Kantor Unit Sentani Kabupaten Jayapura 4) Jaminan tidak berpengaruh terhadap Loyalitas Nasabah BRI Kantor Unit Sentani Kabupaten Jayapura 5) Empati berpengaruh terhadap Loyalitas Nasabah BRI Kantor Unit Sentani Kabupaten Jayapura.6) Bukti Langsung, kehandalan, daya tanggap, jaminan, dan empati berpengaruh simultan dan signifikan terhadap Loyalitas Nasabah BRI Kantor Unit Sentani Kabupaten Jayapura. 7) Faktor yang dominan berpengaruh terhadap Loyalitas Nasabah BRI Kantor Unit Sentani Kabupaten Jayapura adalah faktor empati.
\end{abstract}

Kata Kunci : Kualitas Jasa, Loyalitas Nasabah.

\section{PENDAHULUAN}

\section{A. Latar Belakang}

Menurut Respati (2016) Salah satu strategi yang dapat menunjang keberhasilan bisnis dalam sektor perbankan adalah berusaha menawarkan kualitas jasa dengan kualitas pelayanan tinggi yang akan nampak dalam kinerja layanan yang ada.Salah satu kontributor yang sering dipakai dalam mengembangkan pengukuran kualitas jasa/pelayanan adalah alat ukur kualitas layanan yaitu SERVQUAL (Service Quality) yang dikembangkan oleh Parasuraman, Zeithmal, dan Berry (1988). Dari skala SERVQUAL ini mereka berpendapat bahwa dalam mengevaluasi kualitas pelayanan disebutkan dalam gambaran 5 dimensi yaitu : bukti fisik, keandalan, daya tanggap, jaminan, dan empati.

Menurut Sudarni (2014) Pelayanan yang berkualitas dan bermutu merupakan salah satu cara agar penjualan jasa suatu perusahaan lebih unggul dibandingkan dengan pesaingnya. Tingkat kualitas pelayanan harus dipandang dari penilaian pelanggan. Pelayanan yang baik akan berdampak pada loyalitas pelanggan. Lebih lanjut, oleh Sudarni (2014) Loyalitas diartikan sebagai suatu perilaku yang diharapkan atas produk atau layanan yang antara lain meliputi kemungkinan pembelian lebih lanjut atau sebaliknya perubahan perjanjian pelayanan atau seberapa besar kemungkinan pelangganakan beralih merek atau penyedia pelayanan lain. Kemudian menurut Kusuma (2008) Loyalitas Nasabah akan dapat membangun customer based. Gejolak suku bunga tak akan merontokkan bank bila bank didukung penuh oleh customer based. Untuk itu, bank-bank harus mulai berbenah diri dan makin bersaing dalam merebutkan customer based dengan arena kualitas pelayanan jasa perbankan yang dimiliki.

Efektifitas dan efisiensi usaha suatu bank akan terlihat, sampai dimana bank tersebut mampu untuk memasarkan produk dan jasanya. Untuk memperoleh kepercayaan yang lebih dari nasabah maka di dalam memberikan pelayanan (service) harus dapat menciptakan suasana yang menyenangkan. Seperti yang dikatakan oleh Akbar dalam Kusuma (2016) kepercayaan merupakan kunci dari bisnis perbankan oleh karena itu prinsip kehati-hatian sangat diperlukan. Unsur 
kepercayaan menjadi faktor kunci bagi perusahaan untuk memenangkan persaingan.Kepercayaan juga sangat diperlukan untuk membangun dan mempertahankan hubungan jangka panjang.

Berdasarkan uraian latar belakang diatas, maka penulis tertarik untuk melakukan penelitian dengan judul "Pengaruh Kualitas Jasa Perbankan Terhadap Loyalitas Nasabah Tabungan Simpedes Di Bank Rakyat Indonesia Unit Kantor Cabang Sentani Kabupaten Jayapura.

\section{B. Tujuan Penelitian}

Tujuan yang akan dicapai dari penelitian ini adalah :

1. Untuk mengetahui pengaruh Kualitas Jasa (bukti langsung, kehandalan, daya tanggap, jaminan dan empati) secara parsial terhadap Loyalitas Nasabah Bank Rakyat Indonesia Kantor Unit Sentani Kabupaten Jayapura.

2. Untuk mengetahui pengaruh Kualitas Jasa (bukti langsung, kehandalan, daya tanggap, jaminan dan empati) secara simultan terhadap Loyalitas Nasabah Bank Rakyat Indonesia Kantor Unit Sentani Kabupaten Jayapura.

3. Untuk mengetahui faktor di antara bukti langsung, kehandalan, daya tanggap, jaminan dan empati yang berpengaruh dominan terhadap Loyalitas Nasabah Bank Rakyat Indonesia Kantor Unit Sentani Kabupaten Jayapura.

\section{LANDASAN TEORI}

\section{A. Kajian Teori}

\section{1) Kualitas Jasa}

Menurut Respati (2016) Pelayanan merupakan perilaku dari suatu perusahaan kepada konsumen atau pelanggannya, dan hasil dari aktifitas layanan berupa jasa, sehingga antara jasa dan pelayanan sangat berkaitan, sedangkan pelayanan jasa pada hakekatnya adalah suatu pemecahan masalah. Menurut Riantoro (2016) Kualitas pelayanan yang baik adalah saat perusahaan mampu memberikan pelayanan sesuai permintaan konsumen, mendengarkan segala bentuk keluhkesah konsumen dan memberikan reaksi yang positif terhadap keluh-kesah konsumen sehingga tidak menimbulkan persepsi yang tidak baik atau buruk atas kualitas pelayanan yang diberikan. Untuk mencapai keunggulan kompetitif, kualitas layanan dapat dijadikan alat dan sangat berperan serta menentukan apabila dalam terdapat persaingan dalam usaha merebut pasar dalam kegiatan jasa. Menurut Purnama dalam Dewi (2013) Dimensi Kualitas Jasa adalah sebagai berikut :

a. Bukti Langsung

Bukti Langsung (Tangible) yaitu kemampuan suatu perusahaan dalam menunjukkan eksistensinya kepada eksternal, penampilan dan kemampuan sarana dan prasarana fisik perusahaan, bukti nyata pelayanan yang diberikan oleh pemberi jasa yang meliputi fasilitas fisik (gedung, perlengkapan dan peralatan yang dipergunakan (teknologi) serta penampilan pegawainya.

b. Kehandalan

Kehandalan (Reliability) yaitu kemampuan perusahaan untuk memberikan pelayanan sesuai dengan yang dijanjikan secara akurat dan terpercaya. Kinerja harus sesuai dengan harapan pelanggan yang berarti ketepatan waktu pelayanan yang sama untuk semua pelanggan tanpa kesalahan, sikap yang simpatik dan dengan akurasi yang tinggi.

c. Daya Tanggap

Daya Tanggap (Responsiveness) yaitu suatu kemauan untuk membantu dan memberikan pelayanan yang cepat (responsive) dan tepat pada pelanggan dengan penyampaian informasi yang jelas.Membiarkan nasabah menunggu tanpa adanya suatu alasan yang jelas menyebabkan persepsi yang negatif dalam kualitas pelayanan.

d. Jaminan

Jaminan (Assurance) yaitu pengetahuan, kesopansantunan, dan kemampuan para pegawai perusahaan untuk menumbuhkan rasa percaya para pelanggan kepada perusahaan.

e. Empati

Empati (Empathy) yaitu memberikan perhatian yang tulus dan bersifat individual atau pribadi yang diberikan kepada para pelanggan dengan berupaya untuk memahami keinginan konsumen. Dimana suatu perusahaan diharapkan 
memiliki pengertian dan pengetahuan tentang pelanggan, memahami kebutuhan pelanggan secara spesifik serta memiliki waktu pengoperasian yang nyaman bagi pelanggan.

\section{2) Loyalitas Nasabah}

Menurut Oliver dalam Yusak (2011) loyalitas adalah suatu komitmen yang mendalam untuk membeli atau berlangganan suatu produk atau jasa secara konsisten dimasa yang akan datang sehingga dapat menyebabkan pengulangan pembelian merek yang sama walaupun ada pengaruh situasi dan berbagai usaha pemasaran yang berpotensi untuk memyebabkan tindakan perpindahan merek. Menurut Huriyati dalam Dewi (2013) Pelayanan dan kenyamanan merupakan faktor yang sangat menentukan loyal tidaknya seorang pelanggan, selain itu intensif dan citra toko juga mempengaruhi loyalitas pelanggan. Pelanggan yang loyal merupakan aset penting bagi perusahaan.

Respati (2016) menyatakan bahwa loyalitas pelanggan adalah komitmen pelanggan terhadap suatu merk,toko, atau pemasok, berdasarkan sikap yang sangat positif dan tercermin dalam pembelian ulang yang konsisten. Menurut Maria (2016) ada empat jenis loyalitas pelanggan diantaranya:

a. No Loyalty

No Loyalty tercipta dari rendahnya level ikatan emosional yang terlibat (attachment) dengan rendahnya level pengulangan konsumsi (repeat purchase).

b. Inertia Loyalty

Ketertarikan yang rendah digabung dengan pembelian berulang yang tinggi menghasilkan loyalitas yang lemah.Pelanggan ini membeli karena kebiasaan.

c. Latent Loyalty

Tingkat preferensi yang relatif tinggi digabung dengan tingkat pembelian berulang yang rendah menunjukan loyalitas tersembunyi (Latent Loyalty).

d. Premium Loyalty

Pada tingkat ini pelanggan merasa bangga dalam menggunakan suatu produk maupun jasa tertentu serta senang membagi informasi mengenai produk maupun jasa tersebut.

Menurut Respati (2016) dengan memberikan pelayanan yang bermutu maka akan menciptakan loyalitas pelanggan yang akan berpengaruh pada kemajuan perusahaan dan meningkatkan laba perusahaan.Bila kualitas baik atau melebihi harapan maka pelanggan akan merasa puas. Kemudian menurut Griffin (2009) karakteristik pelanggan yang loyal dapat diukur dengan cara antara lain :

a. Transaksi berulang

Ada sebuah tindak lanjut untuk melakukan transaksi berulang atau rutin ditempat yang sama.

b. Merekomendasikan kepada orang lain

c. Adanya kenyamanan dan kepuasan tersendiri yang dapat dirasakan maka seseorang akan merekomendasikan pemberitaan tentang apa yang dirasakannya tersebut kepada orang lain.

d. Menggunakan jasa lain yang ditawarkan

Kepuasan yang dirasakannya pada suatu jasa, maka akan ada dorongan untuk mencoba tawaran jasa lain yang tersedia di tempat tersebut.

e. Tidak terpengaruh tawaran dari pesaing

Tidak akan mudah tergiur oleh tawaran dari produk sejenis pesaing, karena sudah terbentuk kenyamanan dalam diri selama mengkonsumsi jasa di tempat tersebut.

\section{3) Kerangka Pemikiran}

Dalam penelitian ini penulis menganalisis tentang pengaruh Kualitas Jasa yang terdiri dari Bukti langsung, Kehandalan, Daya Tanggap, Jaminan dan Empat terhadap Loyalitas Nasabah Bank BRI Kantor Cabang Sentani Kabupaten Jayapura. Penulis melakukan analisa dengan pengujian pengaruh secara parsial (masing-masing), simultan (kelompok) dan Dominan (yang paling berpengaruh).Berikut dibawah ini adalah penggambaran peta konsep kerangka pemikiran. 


\section{Gambar 1. Kerangka Berpikir}

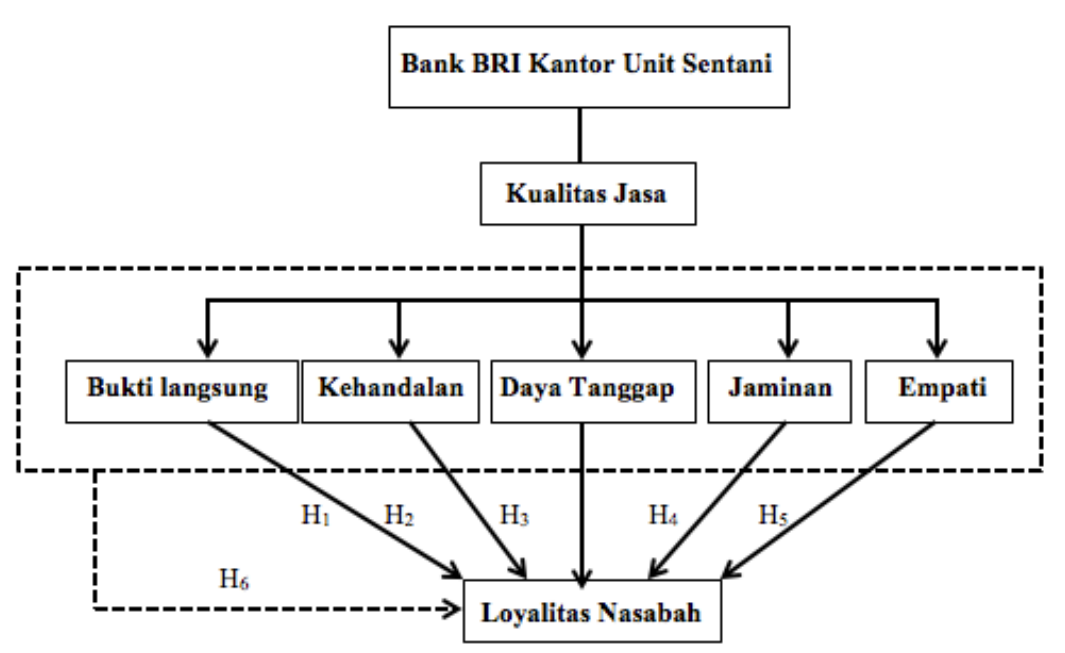

\section{Keterangan :}

: Pengaruh Parsial

: Pengaruh Simultan

\section{4) Hipotesis}

Beberapa hipotesis dalam penelitian ini adalah :

H1 : Diduga Kualitas Jasa (bukti langsung, kehandalan, daya tanggap, jaminan dan empati) secara parsial berpengaruh terhadap Loyalitas Nasabah Bank Rakyat Indonesia Kantor Cabang Sentani Kabupaten Jayapura?

H2 : Diduga Kualitas Jasa (bukti langsung, kehandalan, daya tanggap, jaminan dan empati) secara simultan berpengaruh terhadap Loyalitas Nasabah Bank Rakyat Indonesia Kantor Cabang Sentani Kabupaten Jayapura?

H3 : Diduga faktor empati, merupakan faktor dominan yang berpengaruh terhadap Loyalitas Nasabah Bank Rakyat Indonesia Kantor Cabang Sentani Kabupaten Jayapura?

\section{METODE PENELITIAN}

\section{A. Lokasi dan Waktu Penelitian}

Lokasi penelitian diKantor Bank BRI Kantor Cabang Sentani Kabupaten Jayapuradan penelitian dilakukan pada bulanJuni Tahun 2020.

\section{B. Populasi dan Sampel}

Sugiyono (2007) mendefinisikan populasi sebagai wilayah generalisasi yang terdiri atas objek/subjek yang mempunyai kualitas dan karakteristik tertentu yang ditetapkan oleh peneliti untuk dipelajari dan kemudian ditarik kesimpulannya. Populasi dalam penelitian ini adalah seluruh nasabahTabungan Simpedes pada Bank BRI Kantor Cabang Sentani Kabupaten Jayapura. Menurut Widiyanto, (2013) sampel adalah sebagian dari populasi yang akan diteliti dan dianggap telah mewakili dari populasi.Menurut Purba (1996), jika jumlah populasi tidak diketahui, maka jumlah sampel minimal ditentukan dengan rumus: 
Dimana :

$$
N=\frac{Z^{2}}{4(M E O)^{2}}
$$

$\mathrm{N} \quad=$ Jumlah sampel

$Z=$ Tingkat distribusi normal pada taraf signifikan $5 \%=1,96$

$\mathrm{MOE}=$ Margin of eror max, yaitu tingkat kesalahan maksimal pengambilan sampel yang masih dapat ditoleransi atau yang diinginkan.

Dengan menggunakan margin o eror max sebesar $10 \%$, maka jumlah sampel minimal yang dapat diambil sebesar :

$\mathrm{n}=1,962 / 4(0,10) 2$

$\mathrm{n}=96,04$ atau 97

Berdasarkan perhitungan diperoleh jumlah sampel minimal yang harus dipenuhi sebanyak 100 responden.Teknik pengambilan sampel menggunakan teknik purposive sampling yaitu penetapan sampel berdasarkan kriteria yang telah ditetapkan. Kriteria penetapan sampel adalah sebagai berikut :

1. Kriteria Inklusi

a. Bersedia menjadi responden

b. Nasabah Tabungan Simpedes Bank BRI Kantor Cabang Sentani

2. Kriteria Ekslusi

a. Tidak bersedia menjadi responden

b. Bukan Nasabah Tabungan Simpedes Bank BRI Kantor Cabang Sentani.

\section{Jenis dan Sumber Data}

Desain penelitian yang digunakan dalam penelitian adalah Deskriptif kuantitatif. Menurut Arikunto (2002) Penelitian deskriptif adalah penelitian yang bermaksud menggambarkan fenomena pada obyek peneliti apa adanya. Sedangkan metode kuantitatif adalah metode yang di gunakan untuk pengujian hasil penelitian yang di dasarkan pada angka-angka hasil analisis statistic dan menggunakan teknik survey. Sementara sumber data yang digunakan berupa; a). Data primer, yaitu sumber data penelitian yang diperoleh secara langsung dari sumber aslinya menggunakan kuesioner, jejak pendapat dari individu atau kelompok (orang) maupun hasil observasi dari suatu objek, kejadian atau hasil pengujian(benda). Dengan kata lain, peneliti membutuhkan pengumpulan data dengan cara menjawab pertanyaan riset atau penelitian benda, dan b). Data sekunder yaitu sumber data penelitian yang dipeoleh melalui media perantara atau tidak langsung yang berupa buku, catatan, bukti yang telah ada, atau arsip yang dipublikasikan secara umum. Dengan kata lain, peneliti membuthkan pengumpulan data dengan cara berkunjung ke perpustakaan, pusat kajian, pusat arsip yang berhubungan dengan penelitian.

\section{Teknik Analisis Data}

Penelitian ini menggambarkan suatu hubungan dimana satu atau lebih variabel (variabel independen) mempengaruhi variabel lainnya (variabel dependen).Oleh karena itu peneliti menggunakan analisis regresi sederhanauntuk menguji hipotesis dalam penelitian ini.Dalam analisis regresi linier sederhana, selain mengukur kekuatan pengaruh variabel independen terhadap variabel dependen juga menunjukkan arah pengaruh tersebut. Pengujian tersebut didasarkan pada persamaan regresi linier berganda sebagai berikut :

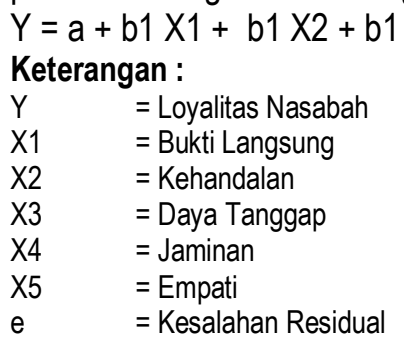




\section{HASIL DAN PEMBAHASAN}

\section{A. Hasil Pengujian Hipotesis}

Pengujian hipotesis dilakukan dengan menggunakan uji regresi linear berganda.Pengujian ini bertujuan untuk mengetahui apakah variabel bukti langsung, kehandalan, daya tanggap, jaminan, dan empati berpengaruh secara signifikan terhadap loyalitas nasabah. Analisis regresi linear berganda dilakukan dengan menggunakan metode enter, karena dengan metode enter seluruh variabel akan dimasukan ke dalam analisis untuk mengetahui seberapa besar pengaruh variabel independen terhadap variabel dependen. Data akan diolah dengan metode enter pada input alat bantu program statistic dan dihasilkan output pada tabel 4.15 berikut ini :

Tabel 1.

Variabel Entered/Removed

\begin{tabular}{|c|l|l|l|}
\hline Model & Variables Entered & Variables Removes & Method \\
\hline \multirow{4}{*}{1} & $\begin{array}{l}\text { Bukti Langsung (X1), } \\
\text { Kehandalan (X2), Daya }\end{array}$ & & \\
& $\begin{array}{l}\text { Tanggap (X3), Jaminan } \\
\text { (X4), Empati (X5) }\end{array}$ & & Enter \\
\hline
\end{tabular}

Dependent Variabel: Loyalitas_nasabah

All request variables entered.

Data diolah, 2020

Berdasarkan tabel 4.15, Variables Entered/Removed analisis statistic deskriptif yaitu sebagai berikut :

a. Variabel yang dimasukkan kedalam persamaan adalah variabel independen yaitu Bukti Langsung (X1), Kehandalan (X2), Daya Tanggap (X3), Jaminan (X4), dan Empati (X5).

b. Tidak ada variabel dependen yang dikeluarkan (Removed).

c. Metode yang digunakan untuk memasukkan data yaitu metode enter.

\section{Tabel 2. Regresi Linear Berganda Coefficients $^{a}$}

\begin{tabular}{|c|c|c|c|c|c|}
\hline \multirow{2}{*}{ Model } & \multicolumn{2}{|c|}{ Unstandardized coefficients } & Standartdized Coefficients & \multirow{2}{*}{$\mathbf{t}$} & \multirow{2}{*}{ Sig. } \\
\cline { 2 - 4 } & $\mathbf{B}$ & Std. Error & Beta & & \\
\hline (Constant) & 16,198 & 2,864 & & 5,655 & 0 \\
\hline Bukti Langsung (X1) & 0,474 & 0,206 & 0,329 & 2,305 & 0,023 \\
\hline Kehandalan (X2) & 0,249 & 0,206 & 0,244 & 2,609 & 0,011 \\
\hline Daya Tanggap (X3) & $-0,343$ & 0,276 & $-0,221$ & $-1,246$ & 0,216 \\
\hline Jaminan (X4) & $-0,162$ & 0,21 & 0,115 & 0,769 & 0,444 \\
\hline Empati (X5) & 0,513 & 0,232 & 0,381 & 2,207 & 0,03 \\
\hline
\end{tabular}

a. Dependent Variable: Loyalitas Nasabah (Y)

Sumber : Hasil Data SPSS, 2020

Dari tabel 4.16 di atas, dapat diperoleh model persamaan regresi $Y=a+B 1 X 1+B 2 X 2+B 3 X 3+B 4 X 4+B 5 X 5+e$, dari hasil analisis diperoleholeh persamaan $Y=16,198+0,474 X 1+0,249 X 2+-0,343 X 3+-0,162 X 4+0,513 X 5+$ e. persamaan tersebut menunjukkan interpensi sebagai berikut :

a. Nilai konstanta sebesar 16,198 menunjukkan arah yang positif dan hal ini mengandung makna bahwa nilai Loyalitas Nasabah sebesar 16,198 satuan nilai tanpa dipengaruhi adanya variabel Bukti Langsung, Kehandalan, Daya Tanggap, Jaminan, dan Empati. 
b. Nilai koefisien regresi variabel Bukti Langsung (X1) sebesar 0,474 memiliki arah yang positif dan mengandung makna bahwa apabila Bukti Langsung meningkat sebesar satuan maka akan berdampak pada meningkatnya Loyalitas Nasabah sebesar 0,474 satuan atau sebesar $4,74 \%$ dengan asumsi nilai variabel lainnya tetap.

c. Nilai koefisein regresi variabel Kehandalan (X2) sebesar 0,249 memiliki arah yang positif dan mengandung makna apabila Kehandalan meningkat sebesar satu satuanan maka akan berdampak pada meningkatnya Loyalitas Nasabah sebesar 0,249 satuan atau sebesar 2,49\% dengan asumsi nilai variabel lainnya tetap.

d. Nilai koefisien regresi variabel Daya Tanggap (X3) sebesar -0,343 memiliki arah yang negatif dan mengandung makna bahwa apabila Daya Tanggap meningkat sebesar satu satuan maka akan berdampak pada menurunnya Loyalitas Nasabah sebesar $-0,343$ satuan atau sebesar $3,43 \%$ dengan asumsi bahwa nilai variabel lainnya tetap.

e. Nilai koefisien regresi variabel Jaminan (X4) sebesar -0,162 memiliki arah yang negative dan mengandung makna bahwa apabila Jaminan meningkat sebesar satu satuan maka akan berdampak pada menurunnya Loyalitas Nasabah sebesar $-0,162$ satuan atau sebesar $1,62 \%$ dengan asumsi bahwa nilai variabel lainnya tetap.

f. Nilai koefisien regresi variabel Empati (X5) sebesar 0,513 memiliki arah yang positif dan mengandung makna bahwa apabila Empati meningkat sebesar satu satuan maka akan berdampak pada meningkatnya Loyalitas Nasabah sebesar 0,513 satuan atau sebesar $5,13 \%$ dengan asumsi bahwa nilai variabel lainnya tetap.

\section{Uji t (Parsial)}

Uji t (parsial) digunakan untuk menguji hipotesis pengaruh variabel bebas secara parsial terhadap variabel terikat. Taraf signifikansi yang digunakan adalah $5 \%$ atau $a=0.05$. Berdasarkan hasil analisis SPSS 25.0 for windows pada tabel 4.16 diatas memberikan gambaran sebagai berikut :

a. Variabel Bukti Langsung

Berdasarkan hasil analisis regresi diperoleh nilai $t_{\text {hitung }} 2,305>t_{\text {tabel }} 1,660$ dan nilai signifikan (Sig) $0,02<0,05$. Maka dapat disimpulkan bahwa $\mathrm{H}_{1}$ diterima, yang artinya bukti langsung $(\mathrm{X} 1)$ berpengaruh secara signifikan terhadap loyalitas nasabah (Y).

b. Variabel Kehandalan

Berdasarakan hasil analisis regresi diperoleh nilai $t_{\text {hitung }} 2,609>t_{\text {tabel }} 1,660$ dan nilai signifikan (Sig) $0,01<0,05$. Maka dapat disimpulkan bahwa $\mathrm{H}_{2}$ diterima, yang artinya kehandalan (X2) berpengaruh signifikan terhadap loyalitas nasabah $(\mathrm{Y})$.

c. Variabel Daya Tanggap

Berdasarkan hasil analisis regresi diperoleh nilai thitung $-1,246>t_{\text {tabel }} 1,660$ dan nilai signifikan (Sig) 0,21> 0,05. Maka dapat disimpulkan bahwa $\mathrm{H}_{3}$ ditolak, yang artinya daya tanggap $(\mathrm{X} 3)$ tidak berpengaruh terhadap loyalitas nasabah ( $\mathrm{Y}$ ).

d. Variabel Jaminan

Berdasarkan hasil analisis regresi diperoleh nilai thitung $-0,769<t_{\text {tabel }} 1,660$ dan nilai signifikan (Sig) 0,44> 0,05. Maka dapat disimpulkan bahwa $\mathrm{H}_{3}$ ditolak, yang artinya jaminan (X4) tidak berpengaruh terhadap loyalitas nasabah (Y).

e. Variabel Empati

Berdasarkan hasil analisis regresi diperoleh nilai $t_{\text {hitung }} 2,207>t_{\text {tabel }} 1,660$ dan nilai signifikan (Sig) $0,03<0,05$. Maka dapat disimpulkan empati (X5) berpengaruh secara signifikan terhadap loyalitas nasabah (Y).

\section{Uji F (Uji Simultan)}

Untuk menguji hipotesis variabel bebas secara simultan terhadap variabel terikat. Tingkat signifikansi yang digunakan adalah $5 \%$ atau $a=0,05$, artinya kemungkinan munculnya kesalahan dalam menerapkan hasil penelitian pada populasi adalah 5\%. Hipotesis penelitian yang diajukan adalah bukti langsung, kehandalan, daya tanggap, jaminan dan empati secara simultan berpengaruh terhadap loyalitas nasabah.Pengujian hipotesis dilakukan dengan membandingkan tingkat sig ( $p$ value) dengan tingkat alpha yang dipersyaratkan yaitu $<0.05$. 
Tabel 3. Hasil Analisis Uji F

$\begin{aligned} & \text { ANOVA } \\
& \text { Model }\end{aligned}$
\begin{tabular}{lllllll} 
& & & & & \\
\hline 1 & Regression & 233.314 & 5 & 46.663 & 5.509 & $.000^{\mathrm{b}}$ \\
\cline { 2 - 7 } & Residual & 796.246 & 94 & 8.471 & & \\
\cline { 2 - 7 } & Total & 1029.560 & 99 & & & \\
\hline
\end{tabular}

a. Dependent Variable: $Y$

b. Predictors: (Constant), X5, X2, X1, X4, X3

\section{Uji Koefisien Determinasi (Adjusted R²)}

Besarnya kontribusi faktor bukti langsung, kehandalan, daya tanggap, jaminan, dan empati terhadap loyalitas nasabah dapat diketahui melalui koefisien determinasinya (Adjusted $R^{2}$ ) yaitu sebesar 0,185 atau 18,5\%. Hal ini berarti loyalitas nasabah dapat dipengaruhi oleh faktor bukti langsung, kehandalan, daya tanggap, jaminan dan empati sebesar 18,5\%, sedangkan sisanya merupakan kontribusi dari faktor lain yang tidak dibahas dalam penelitian ini.

Tabel 4. Hasil Analisis Uji F

\begin{tabular}{|c|c|c|c|c|}
\hline Model & $R$ & R Square & $\begin{array}{c}\text { Adjusted R } \\
\text { Square }\end{array}$ & $\begin{array}{c}\text { Std.Error of the } \\
\text { Estimate }\end{array}$ \\
\hline 1 & $0,476 a$ & 0,227 & 0,185 & 0,291 \\
\hline
\end{tabular}

Hasil analisis dengan menggunakan program SPSS versi 25.0 for windows diperoleh nilai $F_{\text {hitung }}$ sebesar $5,509>F_{\text {tabel }} 2,31$ sedang nilai sig ( $p$ value) sebesar 0,00 . Hal tersebut menunjukkan $0,00<0,05$ nilai $(\mathrm{sig})=0,00<$ alpha yang dipersyaratkan $(0,05)$, dengan demikian hipotesis diterima, sehingga bukti langsung, kehandalan, daya tanggap, jaminan, dan empati secara simultan berpengaruh signifikan terhadap Loyalitas Nasabah.

\section{B. Pembahasan}

1. Pengaruh Bukti Langsung terhadap Loyalitas Nasabah Bank Rakyat Indonesia Kantor Unit Sentani Kabupaten Jayapura.

Hasil penelitian ini menunjukkan bahwa bukti langsung berupa (fasilitas fisik, perlengkapan, pegawai, sarana komunikasi) berpengaruh positif dan signifikan terhadap loyalitasnasabah Bank Rakyat Indonesia Kantor Unit Sentani Kabupaten Jayapura. Artinya apabila bukti langsung seperti fasilitas fisik, perlengkapan pegawai, dan sarana komunikasi semakin ditingkatkan maka akan berdampak positif dan signifikan pada loyalitas nasabah Bank Rakyat Indonesia Kantor Unit Sentani Kabupaten Jayapura.

Penelitian ini sejalan dengan penelitian Riantoro (2016) hasil penelitiannya menunjukkan bahwa bukti fisik berpengaruh secara parsial terhadap loyalitas nasabah bank BRI Cabang Sukoharjo. Penelitian ini juga mendukung penelitian yang dilakukan oleh Sudarni (2014) hasil penelitiannya menunjukkan bahwa bukti langsung berpengaruh signifikan terhadap loyalitas nasabah PT. Bank Muamalat, Tbk. Cabang Pembantu Subolga.Selain itu juga, penelitian ini mendukung penelitian Kusuma (2008) hasil penelitiannya menunjukkan bahwa bukti langsung berpengauh signifikan terhadap kepuasan nasabah dan dampak terhadap loyalitas nasabah Bank Niaga Semarang.

\section{Pengaruh Kehandalanterhadap Loyalitas Nasabah Bank Rakyat Indonesia Kantor Unit Sentani Kabupaten Jayapura.}

Hasil penelitian ini menunjukkan bahwa kehandalan berupa (pelayanan tepat waktu, sikap simpatik, teliti dalam melayani nasabah) berpengaruh positif dan signifikan terhadap Loyalitas Nasabah Bank Rakyat Indonesia Kantor Unit Sentani Kabupaten Jayapura. Layanan yang bias diandalkan dalam variabel kehandalan adalah pelayanan tepat waktu, sikap simpatik, teliti dalam melayani nasabah. Para nasabah umumnya lebih memperhatikan kemudahan dan kecepatan 
dalam bertransaksi tanpa kesalahan. Oleh karena itu, kesenjangan antara penyampaian jasa dan komunikasi yang baik dan kecenderungan memberikan janji yang berlebihan dapat menyebabkan nasabah meninggalkan dan beralih ke bank lain.

Hasil penelitian ini mendukung penelitian yang dilakukan oleh Sudarni (2014) hasil penelitiannya menunjukkan bahwa kehandalan berpengaruh signifikan terhadap loyalitas nasabah PT. Bank Muamalat, Tbk. Cabang Pembantu Subolga. Selain itu juga, penelitian ini mendukung penelitian Kusuma (2008) hasil penelitiannya menunjukkan bahwa kehandalan berpengauh signifikan terhadap kepuasan nasabah dan dampak terhadap loyalitas nasabah Bank Niaga Semarang.

Menurut Purnama dalam Dewi (2013) salah satu Dimensi Kualitas Jasa adalah Kehandalan (Reliability) yaitu kemampuan perusahaan untuk memberikan pelayanan sesuai dengan yang dijanjikan secara akurat dan terpercaya. Kinerja harus sesuai dengan harapan pelanggan yang berarti ketepatan waktu pelayanan yang sama untuk semua pelanggan tanpa kesalahan, sikap yang simpatik dan dengan akurasi yang tinggi.

Kemudian hal yang sama juga dikatakan oleh Tjiptono dalam Hais (2010)bahwaReliability, yaitu kemampuan memberikan layanan jasa atau jasa yang diharapkan secara meyakinkan, akurat dan konsisten dan memuaskan.

Kesigapan karyawan BRI untuk membantu memecahkan masalah yang dihadapi oleh nasabah merupakan daya tarik tersendiri.Hal ini dapat memberikan penilaian positif terhadap BRI atas kualitas layanan yang diberikan jika disampaikan dengan baik, karena adanya interaksi langsung antara nasabah dengan karyawan. Komunikasi antara karyawan dan nasabah harus dapat membuat nasabah senang, kesenangan akan menciptakan ikatan emosional terhadap perusahaan yang hasilnya adalah loyalitas nasabah yang tinggi. Jika nasabah mempunyai masalah, mereka tidak akan segan untuk mengemukakanya kepada karyawan.

Seperti yang dikatakan oleh Buchari Alma dalam Maria (2016) bahwa Reliability (Kehandalan) Kemampuan perusahaan untuk memberikan pelayanan sesuai dengan yang dijanjikan secara akurat dan terpercaya. Kinerja harus sesuai dengan harapan pelanggan yang berarti ketepatan waktu, pelayanan yang sama untuk setiap pelanggan yang sama tanpa kesalahan, sikap yang simpatik, dan dengan akurasi yang tinggi.

\section{Pengaruh Daya Tanggap terhadap Loyalitas Nasabah Bank Rakyat Indonesia Kantor Unit Sentani Kabupaten Jayapura.}

Hasil penelitian ini menunjukkan bahwa daya tanggap tidak berpengaruh terhadap Loyalitas Nasabah Bank Rakyat Indonesia Kantor Unit Sentani Kabupaten Jayapura. Artinya indikator daya tanggap seperti memberikan informasi yang jelas, cepat merespon kebutuhan nasabah tidak memberikan pengaruh yang signifikan terhadap peningkatan loyalitas nasabah.

Hasil penelitian ini mendukung penelitian yang dilakukan oleh Riantoro (2016) hasil penelitiannya menunjukkan bahwa daya tanggap tidak berpengaruh terhadap loyalitas nasabah bank BRI Cabang Sukoharjo. Selain itu juga, penelitian ini mendukung penelitian Kusuma (2008) hasil penelitiannya menunjukkan bahwa daya tanggap tidak berpengauh signifikan terhadap kepuasan nasabah dan dampak terhadap loyalitas nasabah Bank Niaga Semarang.

Menurut Hasibuan dalam Dewi (2013) Pelayanan nasabah dalam dunia jasa menjadi sesuatu hal yang penting. Hal ini mengingat sifat jasa yang salah satunya adalah tidak berwujud (intangible) memerlukan umpan balik untuk menilai kualitas layanannya.

\section{Pengaruh Jaminan (mempunyai pengetahuan yang luas, bersikap sopan, dapat menumbuhkan kepercayaan) terhadap Loyalitas Nasabah Bank Rakyat Indonesia Kantor Unit Sentani Kabupaten Jayapura.}

Hasil penelitian ini menunjukkan faktor Jaminan tidak berpengaruh terhadap Loyalitas Nasabah Bank Rakyat Indonesia Kantor Unit Sentani Kabupaten Jayapura.Artinya indikator-indikator jaminan seperti mempunyai pengetahuan yang luas, bersikap sopan, dapat menumbuhkan kepercayaan tidak mampu meningkatkan loyalitas nasabah Bank Rakyat Indonesia Kantor Unit Sentani Kabupaten Jayapura.

Hasil penelitian ini mendukung penelitian yang dilakukan oleh Riantoro (2016) hasil penelitiannya menunjukkan bahwa jaminan tidak berpengaruh terhadap loyalitas nasabah bank BRI Cabang Sukoharjo. Selain itu juga, penelitian ini mendukung penelitian Kusuma (2008) hasil penelitiannya menunjukkan bahwa jaminan tidak berpengauh signifikan terhadap kepuasan nasabah dan dampak terhadap loyalitas nasabah Bank Niaga Semarang. 


\section{Pengaruh Empati (komunikasi yang baik, perhatian terhadap nasabah) terhadap Loyalitas Nasabah Bank} Rakyat Indonesia Kantor Unit Sentani Kabupaten Jayapura.

Hasil penelitian ini menunujukkan bahwa faktor Empati (komunikasi yang baik, perhatian terhadap nasabah) berpengaruh positif dan signifikan terhadap loyalitas Nasabah Bank Rakyat Indonesia Kantor Unit Sentani Kabupaten Jayapura.Artinya faktor empati seperti komunikasi yang baik, perhatian terhadap nasabah dapat memberikan pengaruh positif dan signifikan terhadap peningkatan Loyalitas Nasabah Bank Rakyat Indonesia Kantor Unit Sentani Kabupaten Jayapura.

Penelitian ini sejalan dengan penelitian Riantoro (2016) hasil penelitiannya menunjukkan bahwa empati berpengaruh signifikan terhadap loyalitas nasabah bank BRI Cabang Sukoharjo. Penelitian ini juga mendukung penelitian yang dilakukan oleh Sudarni (2014) hasil penelitiannya menunjukkan bahwa empati berpengaruh signifikan terhadap loyalitas nasabah PT. Bank Muamalat, Tbk. Cabang Pembantu Subolga.Selain itu juga, penelitian ini mendukung penelitian Kusuma (2008) hasil penelitiannya menunjukkan bahwa empati berpengauh signifikan terhadap kepuasan nasabah dan dampak terhadap loyalitas nasabah Bank Niaga Semarang.

\section{Pengaruh Bukti Langsung, Kehandalan, Daya Tanggap, Jaminan, Empati secara simultan terhadap Loyalitas Nasabah Bank Rakyat Indonesia Kantor Unit Sentani Kabupaten Jayapura.}

Hasil penelitian menunjukkan bahwa bukti langsung, kehandalan, daya tanggap, jaminan, dan empati berpengaruh secara simultan terhadap loyalitas nasabahBank Rakyat Indonesia Kantor Unit Sentani Kabupaten Jayapura.Artinya indikator kualitas layanan seperti bukti langsung, kehandalan, daya tanggap, jaminan, empati secara bersama-sama dapat memberikan pengaruh yang signifikan terhadap loyalitas nasabah Bank Rakyat Indonesia Kantor Unit Sentani Kabupaten Jayapura.

Penelitian ini sejalan dengan penelitian Dama (2010) hasil penelitiannya menunjukkan bahwa Secara simultan berdasarkan analisi yang digunakan maka dimensi kualitas pelayanan secara nyata dan positif berpengaruh terhadap loyalitas nasabah Bank Mandiri Cabang Gorontalo. Penelitian ini juga mendukung penelitian yang dilakukan oleh Riantoro (2016) hasil penelitiannya menunjukkan Kualitas pelayanan secara bersama-sama sangat berpengaruh terhadap loyalitas nasabah bank BRI Cabang Sukoharjo.

Penelitian ini juga mendukung pendapat Purnama dalam Dewi (2013) yang menyatakan bahwa Dimensi Kualitas Jasa adalah bukti langsung, kehandalan, daya tanggap, jaminan, empati. Selain itu juga mendukung pendapat Tjiptono dalam Hais (2010) ada 5 (lima) dimensi kualitas pelayanan yaitu:Tangible, Empathy, Reliability, ResponsivenessdanAssurance.

Hasil pengukuran pada kelima variabel tersebut menunjukkan bahwa telah dilakukan dengan baik oleh petugas Bank Rakyat Indonesia Kantor Unit Sentani Kabupaten Jayapura.Hal ini memberikan dampak baik terhadap loyalitas nasabah Bank Rakyat Indonesia Kantor Unit Sentani Kabupaten Jayapura.

\section{Faktor yang dominan berpengaruh terhadap Loyalitas Nasabah Bank Rakyat Indonesia Kantor Unit Sentani Kabupaten Jayapura}

Hasil penelitian menunjukkan bahwa faktor yang dominan berpengaruh terhadap Loyalitas Nasabah BRI Kantor Unit Sentani Kabupaten Jayapura adalah faktor empati.Hal ini memberikan gambaran bahwa loyalitas nasabah Bank Rakyat Indonesia Kantor Unit Sentani Kabupaten Jayapura lebih dipengaruhi oleh empati yang ditunjukkan petugas kepada nasabah seperti komunikasi yang baik, perhatian terhadap nasabah.

Menurut Imam dalam Dewi (2013) Ketika pelanggan merasa terpenuhi harapannya akan pelayanan yang didapatkan pada saat proses transaksi dan barang atau jasa yang mereka dapatkan, maka pelanggan akan kembali lagi dan melakukan pembelian-pembelian yang lain di perusahaan yang sama dan juga akan merekomendasikan kepada orang lain tentang perusahaan tersebut

Dengan memberikan pelayanan yang bermutu maka akan menciptakan loyalitas pelanggan yang akan berpengaruh pada kemajuan perusahaan dan meningkatkan laba perusahaan. Bila kualitas baik atau melebihi harapan maka pelanggan akan merasa puas.Seperti yang dikatakan oleh Akbar dalam Kusuma (2016) kepercayaan merupakan kunci dari bisnis perbankan oleh karena itu prinsip kehati-hatian sangat diperlukan. Unsur kepercayaan menjadi faktor kunci bagi perusahaan untuk memenangkan persaingan.Kepercayaan juga sangat diperlukan untuk membangun dan mempertahankan hubungan jangka panjang. 


\section{PENUTUP}

\section{A. Simpulan}

Berdasarkan hasil penelitian dan pembahasan, maka dapat disimpulkan sebagai berikut :

1. Bukti Langsung berpengaruh positif dan signifikan terhadap Loyalitas Nasabah BRI Kantor Unit Sentani Kabupaten Jayapura.

2. Kehandalan berpengaruh positif dan signifikan terhadap Loyalitas Nasabah BRI Kantor Unit Sentani Kabupaten Jayapura.

3. Daya Tanggap tidak berpengaruh terhadap Loyalitas Nasabah BRI Kantor Unit Sentani Kabupaten Jayapura.

4. Jaminan tidak berpengaruh terhadap Loyalitas Nasabah BRI Kantor Unit Sentani Kabupaten Jayapura.

5. Empati berpengaruh terhadap Loyalitas Nasabah BRI Kantor Unit Sentani Kabupaten Jayapura.

6. Bukti Langsung, kehandalan, daya tanggap, jaminan, dan empati berpengaruh simultan dan signifikan terhadap Loyalitas Nasabah BRI Kantor Unit Sentani Kabupaten Jayapura.

7. Faktor yang dominan berpengaruh terhadap Loyalitas Nasabah BRI Kantor Unit Sentani Kabupaten Jayapura adalah faktor empati.

\section{B. Saran}

Berdasarkan kesimpulan di atas, maka penulis memberikan saran dan masukan sebagai berikut :

1. Bank BRI Kantor Unit Sentani

a. Petugas BRI kantor Unit Sentani harus lebih meningkatkan pengetahuan yang luas, bersikap sopan, dapat menumbuhkan kepercayaan dalam melayani nasabah. Sehingga nasabah tertark untuk datang dan memilih BRI sebagai layanan bank.

b. BRI harus memaksimalkan karyawan baris depan dalam memberikan informasi ataupun prosedur untuk melakukan transaksi dengan bank yang bersangkutan agar pelaksanaan transaksi dapat dilakukan dengan tertib sesuai dengan nomor urutan.

2. Peneliti selanjutnya

Kepada peneliti selanjutnya dapat menjadikan penelitian ini sebagai referensi atau rujukan apabila melakukan penelitian sejenis pada pengukuran kualitas layanan terhadap loyalitas nasabah bank.

\section{DAFTAR PUSTAKA}

Sundari, Sri .2011. Hubungan Corporate Social Responsibility dengan kinerja Perusahaan.Perpustakaan Unhas. Universitas Hasanuddin. Makassar.

Arikunto, Suharsimi. 2002. Prosedur Penelitian Suatu Pendekatan Praktek. Jakarta: Rineka Cipta

Alma, Buchari (2011). Manajemen Pemasaran dan PemasaranJasa. Cetak Kedelapan Bandung: Alfabeta

Caruana A. and Fenech N. 2005. The Effect of Perceived Value and Overall Satisfaction on Loyalty: A Study among Dental Patients. Journal of Medical Marketing. Vol.5 No.3 Pp. 245-255

Dewi, Lestari, Anis. 2013. Analisis Pengaruh Kualitas Pelayanan Terhadap Loyalitas Nasabah Pada Bank Syariah Mandiri Kantor Cabang Pembantu Banyumanik Semarang. Skripsi.IAIN. Semarang. http://eprints. walisongo.ac.id/1121/. Diakses 27 Februari 2020.

Dessler, Gary. 2015. Manajemen Sumber Daya Manusia. Jakarta: Salemba Empat.

Fajar Laksana, 2008. Manajemen Pemasaran, Yogyakarta : Graha Ilmu. 
Fandy Tjiptono. 2005. Pemasaran Jasa, Edisi Pertama, Cetakan Pertama

Griffin, Jill, 2009. Customer Loyalty, Menumbuhkan dan Mempertahankan Kesetiaan Pelanggan, Erlangga, Jakarta

Ghozali, Imam. 2009. Aplikasi Analisis Multivriate dengan Program SPSS. Semarang: Badan Penerbit Universitas Dipenogoro

Hurriyati, Ratih, 2005. Pembauran Pemasaran dan Loyalitas Konsumen, Bandung : Alfa Beta.

Hais, Dama. 2010. Pengaruh Kualitas Pelayanan Terhadap Loyalitas Nasabah Pada Bank Mandiri Cabang Gorontalo. Jurnal. INOVASI, Volume 7, Nomor 2, Juni 2010 ISSN 1693-9034

Hania, Maria. 2016. Pengaruh Kualitas Jasa Perbankan Dengan Menggunakan Internet Banking Terhadap Loyalitas Nasaba.Jurnal. Ecodemica, Vol. IV No.1 April 2016

Hasibuan, Malayu S.P., 2011. Manajemen Sumber Daya Manusia. Bumi Aksara, Jakarta

Imam, Sentot Wahjono, 2010. Manajemen Pemasaran Bank, Yogyakarta : Graha IImu

Januarisya Respati, 2016. Pengaruh Kualitas Pelayanan Terhadap Kepuasan Nasabah Dan Dampaknya Pada Loyalitas Nasabah (Studi Pada Nasabah Tabungan Bank BCA KCU Pusat Kota Malang). Jurnal Administrasi Bisnis (JAB)|Vol. 41 No.1 Desember 2016.

Justine T. Sirait, 2006, Memahami Aspek-aspek Pengelolaan Sumber Daya Manusia dalam Organisasi, PT Grasindo, Jakarta

Kusuma, Indra Maraditya. 2008. Analisis Pengaruh Kualitas Pelayanan Jasa Perbankan Terhadap Kepuasan Nasabah dan Dampaknya Terhadap Loyalitas Nasabah.Jurnal Sains Pemasaran Indonesia.Volume II. Nomor 1, Mei 2008, halaman 1-20.

Kotler, Phillip. 2000. Marketing management. (The Millenium Edition). New Jersey: Prentice-Hall

Laksana, F ajat, 2008, Manajemen Pemasaran Pendekatan Pra\& trs, Penerbit Graha llmu, Yogyakarta

Nawawi, Hadari, Martini,2006. Instrumen Penelitian BidangSosial, Gadjah Mada University Press, Yogyakarta.

Notoatmodjo, S., 1998, Pengembangan Sumber Daya Manusia, Rineka Cipta, Jakarta

Malayu S.P.Hasibuan,2006. Dasar-Dasar Perbankan, Jakarta : PT Bumi Aksara

Oliver, Ricard L. 1993. "Cognitive, Affective, and Attribute Bases of The Satisfaction ". Journal of Consumer Research.Vol.20. No.8. Pp 20-38

Parasuraman A., Valarie A.Zeithaml, Leonard L. Berry, 1988, Servqual : "A Multiple-Item Scala for Measuring Consumer Perception of Service Quality”. Journal of Retailing Vol 64, pp 12-40

Purnama, Nursya'bani, Manajemen Kualitas, Yogyakarta : EKONISIA, 2006 
Riantoro, Ahmad. 2016. Pengaruh Kualitas Pelayanan Terhadap Loyalitas Nasabah Bank Bri Cabang Sukoharjo. Jurnal.FE.UMS.Surakarta. $\quad$ http://docplayer.info/94745633-Pengaruh-kualitas-pelayanan-terhadap-loyalitasnasabah-bank-bri-cabang-sukoharjo.html. Diakses 27 Februari 2020

Rusdarti, 2007, Pengaruh Kualitas Pelayanan dan Nilai Pelayanan Terhadap Loyalitas Nasabah Pada Bank BPD Jawa Tengah Cabang Semarang. Jurnal Bisnis Strategi. Vol. 13. Pp.54-65

Sugiyono. 2007. Metode Penelitian Kuantitatif Kualitatif dan R\&D. Bandung: Alfabeta

Sofjan Assauri, Manajemen Pemasaran, Jakarta : PT Raja Grafindo Persada, 2007, hlm.213

Sondang P. Siagian, 2013, "Manajemen Sumber Daya Manusia”, , Jakarta: Bumi Aksara

Sudarni. 2014. Pengaruh Kualitas Pelayanan Terhadap Loyalitas Nasabah PT. Bank Muamalat, Tbk. Cabang Pembantu Sibolga dengan Kepuasan Nasabah Sebagai Variabel Interventing. TA. UT. Jakarta. http://repository.ut.ac.id/9/. Diakses 28 Februari 2020

Tjiptono, Fandy, 2011. Manajemen Jasa. Yogyakarta: Penerbit Andi.

Usmaru, Usi,2008. Pemikiran Kreatif Pemasaran, Yogyakarta : Amara Books.

Usman, Husaini. 2008. Manajemen. Edisi Kedua. Jakarta. PT. Bumi Kasara.

Wahyu Ariani, 2009, Manajemen Operasi Jasa, Yogyakarta : Graha IImu

Yudi Sutarso, 2005, "Kualitas Jasa dan Budaya dalam perbankan Islam : Fenomena, Pengukuran dan Implikasinya pada Pelanggan". Banking Laporan Journal.Doc.4.

Yusak Ansori, 2011. Pengaruh Kualitas Jasa Perbankan Terhadap Loyalitas Nasabah di Bank Rakyat Indonesia Surabaya.Jurnal of Busines and Banking.Volume 1, No.1, May 2011, paes 39-50. 